\title{
SOME NEW INEQUALITIES FOR AN INTERIOR POINT OF A TRIANGLE
}

\section{JIAN LIU}

Abstract. In this paper we establish three new inequalities involving an arbitrary point of a triangle. Some related conjectures and problems are put forward.

Mathematics subject classification (2010): 51M16.

Keywords and phrases: triangle, interior point, Erdös-Mordell inequality, Euler inequality, conjecture.

\section{REFERENCES}

[1] Jian LiU, Several New Inequalities for the Triangle, Mathematics Competition (in Chinese), Hunan Education Press 15 (1992), 80-100.

[2] D. Mitrinović, J. E. PeČArić, V. Volenec And Ji Chen, Addenda to the Monograph "Recent Advances in Geometric Inequalities” I, Journal of Ningbo University 4, 2 (1991), 79-145.

[3] D. Mitrinović, J. E. Pečarić And V. Volenec, Recent Advances in Geometric Inequalities, Kluwer Academic Publishers, Dordrecht, Boston, London, 1989.

[4] O. Bottema, R. Ž. Djordjević, R. R. Janić, D. S. Mitrinović, and P. M. Vasić, Geometric Inequalities, Groningen, 1969.

[5] V. Komornik, A short proof of the Erdös-Mordell theorem, Amer.Math.Monthly 104 (1997), 57-60.

[6] D. K. KAZARINOFF, A simple proof of the Erdös-Mordell inequality for triangles, Michigan Mathematical Journal 4 (1957), 97-98.

[7] L. BANKOFF, An elementary proof of the Erdös-Mordell theorem, Amer.Math.Monthly 65 (1958), 521.

[8] A. Avez, A short proof of the Erdös and Mordell theorem, Amer.Math.Monthly 100 (1993), 60-62.

[9] H. LEE, Another proof of the Erdös-Mordell theorem, Forum Geom. 1 (2001), 7-8.

[10] N. Dergiades, Signed distances and the Erdös-Mordell inequality, Forum Geom. 4 (2004), 67-68.

[11] Jian LiU, A Geometric Inequality, Bull Math (in Chinese) 9 (1988), 1-3.

[12] JiAn LiU, An Inequality for the polygon, Hunan Bull Math (in Chinese) 6 (1991), 36-37.

[13] Xiao-guang Chu, Zhen-Gang Xiao, The Proof of Some Geometric Inequality Conjecturs (in Chinese), Journal of Hunan Institute of Science Technology (Natural Sciences) 16, 4 (2003), 10-13.

[14] Xue-Zhi Yang, Studies of Olympics Math inequalities, Harbin Institute of Technology Press, Harbin, China, 2009.

[15] JiAn LiU, A new proof of the Erdös-Mordell inequality, Int. Electron. J. Geom, 4, 2 (2011), 114-119. 